\title{
ARTIKEL ILMIAH SEBAGAI SUMBER PEMBELAJARAN BIOKIMIA
}

\author{
Syahmani dan Rahmat Eko Sanjaya \\ Fakultas Keguruan dan Ilmu Pendidikan Universitas Lambung Mangkurat, Indonesia \\ email: sanjaya28_kimia@ulm.ac.id
}

\begin{abstract}
Abstrak
Penelitian ini bertujuan untuk mengetahui pemanfaatan artikel ilmiah dalam pembelajaran biokimia di perguruan tinggi pada konsep metabolisme energi. Penelitian ini menggunakan desain penelitian One Group Pretest-Posttest. Subjek penelitian adalah 22 mahasiswa Program Studi Pendidikan Kimia FKIP Universitas Lambung Mangkurat. Dua proses pembelajaran yang dilakukan pada penelitian ini mengacu kepada pembelajaran aktif, yaitu mahasiswa belajar secara terarah dan dilakukan secara mandiri (Direct Study/DS), kemudian secara kelompok untuk mendiskusikan hasil pekerjaan mandiri (Discussion Group/DG). Data yang diperoleh dalam penelitian adalah hasil belajar mahasiswa berupa pretest dan posttest dan kuesioner. Data tersebut kemudian dianalisis secara kualitatif dan kuantitatif. Hasil penelitian menunjukkan perbedaan yang siginifikan antara pretest dan posttest setelah pembelajaran menggunakan artikel ilmiah sebagai sumber pembelajaran biokimia. Peningkatan pretest dan posttest menghasilkan nilai $n$-gain yang berada pada kategori "sedang". Rata-rata nilai persepsi dan komitmen mahasiswa dalam pembelajaran dengan menggunakan artikel ilmiah berada pada kategori "sedang". Hal ini mengindikasikan bahwa pembelajaran biokimia pada topik metabolisme energi dengan menggunakan artikel ilmiah memberikan dampak positif terhadap hasil belajar dan minat mahasiswa.
\end{abstract}

Kata kunci: artikel ilmiah, sumber pembelajaran, biokimia

\section{SCIENTIFIC ARTICLES AS BIOCHEMISTRY LEARNING RESOURCES}

\begin{abstract}
This study aims to determine the use of scientific articles in biochemical learning in higher education, especially on the energy metabolism concept. This study used a One Group PretestPosttest research design. The research subjects were 22 students of the Chemistry Education Study Program FKIP Universitas Lambung Mangkurat. Two learning processes carried out in this study refer to active learning, namely students learn in a focused and independent manner (Direct Study/DS), then in groups to discuss the results of independent work (Discussion Group/ DG). The data obtained in the study were student learning outcomes in the form of pre-test and post-test and questionnaires. The data were then analyzed qualitatively and quantitatively. The results show a significant difference between the pre-test and post-test after learning using scientific articles as a source of biochemistry learning. The increase in pre-test and post-test resulted in an n-gain value that was in the "medium" category. The average value of students' perceptions and commitments in learning using scientific articles is in the "medium" category. This indicates that learning biochemistry on the topic of energy metabolism using scientific articles has a positive impact on student learning outcomes and interest
\end{abstract}

Keywords: scientific articles, learning resource, biochemistry

\section{PENDAHULUAN}

Pembelajaran ilmu hayati, khususnya biokimia, menuntut adanya kemampuan mahasiswa untuk berpikir ilmiah dan berpikir kritis (Avikasari dkk., 2018) serta mampu mengaplikasikan pengetahuan 
tersebut secara langsung (Rahayu \& Laksono, 2015). Akan tetapi, kebanyakan proses perkuliahan di perguruan tinggi menggunakan sistem pembelajaran konvensional yang hanya berkutat pada perkuliahan oral, membaca buku teks dan bahan tayangan yang dibuat oleh dosen sebagai sumber pembelajaran (Hartman et al., 2017). Akibatnya, pembelajaran hanya mengupas tentang konsep dasar yang tidak melihat pada aplikasi dari konsep tersebut.

Biokimia merupakan ilmu bersifat transdisipliner, yang melibatkan berbagai rumpun ilmu dan terus menerus mengalami perkembangan setiap saat (Bobich, 2008; Bell, 2001). Perkembangan ini hanya dapat dilihat melalui sumber pembelajaran yang bersifat primer. Salah satu sumber pembelajaran yang bersifat primer tersebut adalah artikel ilmiah. Aktikel ilmiah disebut sebagai sumber primer karena berisi pengetahuan baru yang bersumber melalui riset ilmiah secara langsung. Hal ini menjadikan artikel ilmiah dapat menjadi sumber pembelajaran yang terkini dan bersifat langsung atas konsep yang dipelajari oleh mahasiswa. Pada buku teks diajarkan tentang metabolisme, mulai dari glikolisis, dekarboksilasi oksidatif, siklus asam sitrat hingga konsep dasar transfer elektron. Akan tetapi pada artikel ilmiah dapat menjelaskan pemanfaatan konsep tersebut, misalnya bagaimana penggunaan konsep dasar metabolisme energi dalam mengatasi kanker (Akram, 2013).

Pada perkuliahan Biokimia, artikel ilmiah merupakan hal yang tidak dapat dipisahkan. Biokimia dari waktu ke waktu terus mengalami terobosan sehingga pemanfaatan konsep dasar biokimia dan informasi terbaru dari biokimia harus menjadi perhatian mahasiswa dan dosen (Cicuto et al., 2019).

Pembelajaran dengan menggunakan artikel ilmiah memungkinkan mahasiswa dapat memperdalam konsep yang telah mereka pelajari. Pembelajaran menggunakan artikel ilmiah telah digunakan dengan berbagai pendekatan, di antaranya artikel ilmiah untuk mengkaji suatu permasalahan (Drake et al., 1997; Fortner, 1999), bahan diskusi dalam kelompok kecil(Cornely, 1999; Houde, 2000; Levine, 2001; Mulnix, 2003; Walczak \& Jackson, 2007), pembentukan club jurnal (Glazer, 2000; Roberts, 2009) dan sebagai pekerjaan rumah (Roecker, 2007). Pembelajaran dengan artikel ilmiah, pada prakteknya termasuk dalam pembelajaran berbasis inkuiri (Walczak \& Jackson, 2007; Roberts, 2009; Roecker, 2007; Drake et al., 1997; Houde, 2000).

Pembelajaran yang memasukkan unsur berpikir kritis, berpikir ilmiah dan kolaboratif, menuntut pengajar untuk memilih metode dan sumber pembelajaran yang sesuai dengan pengembangan konten pembelajaran biokimia dan menuntut adanya keterampilan ilmiah sehingga diperlukan sebuah metode dan sumber belajar yang dapat digunakan dalam pembelajaran biokimia. Selain itu, diperlukan juga informasi mengenai metode dan sumber belajar tersebut digunakan. Sumber pembelajaran yang dapat digunakan pada lingkungan pembelajaran aktif salah satunya adalah artikel ilmiah (Espadiola et al., 2010; Duncan \& Johnson, 2007), karena menyajikan permasalahan serta informasi terbaru dibandingkan dengan sumber lainnya. Selain itu, artikel ilmiah memiliki tingkat akses yang lebih luas dibandingkan sumber pembelajaran lainnya.

Penggunaan artikel ilmiah sebagai sumber pembelajaran dapat menjadi pendekatan baru dalam mengajarkan biokimia pada mahasiswa. Keuntungan lainnya dalam penggunaan artikel ilmiah sebagai sumber pembelajaran adalah memfasilitasi mahasiswa untuk dapat studi lanjut (Kozeracki et al, 2006), 
meningkatkan kepercayaan diri dalam hal terminologi dan metode ilmiah (Willard \& Brasier, 2014), meningkatkan keterlibatan mahasiswa dalam mengkritisi literatur yang digunakan (Ullrich et al., 2012) dan melatih mahasiswa untuk kritis dan berpikir ilmiah.

Berdasarkan pertimbangan ini, jelas bahwa penting untuk menyelidiki artikel ilmiah dapat menjadi suatu alternatif sumber pembelajaran yang diajarkan secara kolaboratif antarmahasiswa. Oleh karena itu, penelitian ini adalah untuk mengetahui pemanfaatan artikel ilmiah dalam pembelajaran biokimia di perguruan tinggi serta persepsi mahasiswa terhadap pembelajaran yang digunakan, khususnya pada konsep metabolisme energi yang menjadi konsep utama dalam mempelajari proses pembentukan energi yang bersumber dari berbagai biomolekul.

\section{METODE}

Desain penelitian yang digunakan adalah One Group Pretest-Posttest. Subjek penelitian adalah 22 orang mahasiswa Program Studi Pendidikan Kimia FKIP Universitas Lambung Mangkurat pada topik perkuliahan metabolisme karbohidrat. Penelitian dilakukan sebanyak 6 kali pertemuan tatap muka dan 1 kali pertemuan untuk posttest serta pretest dilakukan sebelum jadwal perkuliahan. Strategi pembelajaran yang digunakan adalah pembelajaran aktif berupa diskusi kelompok dan dilengkapi dengan pembelajaran langsung serta tugas mandiri. Penelitian diawali dengan memberikan pretest pada subjek penelitian. Selama perkuliahan, mahasiswa diberikan topik pembelajaran yang terkait dengan metabolisme karbohidrat sesuai dengan Rencana Pembelajaran Semester (RPS) mata kuliah Biokimia 2.

Mahasiswa dalam proses pembelajaran ditugaskan untuk menganalisis artikel ilmiah yang berkaitan dengan topik perkuliahan.
Artikel pertama yang ditugaskan adalah The Intermediate Metabolism of Carbohydrates (Krebs et al., 1937). Pada artikel pertama ini, mahasiswa diberikan keleluasaan untuk melakukan analisis terhadap artikel tentang Siklus Krebs. Sifat penugasan adalah tugas individu serta dilaksanakan diluar waktu perkuliahan tatap muka. Berikutnya, mahasiswa ditugaskan untuk menganalisis artikel ilmiah berdasarkan pertanyaan pemandu (guided questions) yang diberikan. Mahasiswa diminta untuk mencari jawaban terhadap pertanyaan tersebut berdasarkan artikel ilmiah yang disajikan. Artikel ilmiah yang digunakan adalah Minireview on Glycolysis and Cancer (Akram, 2013). Terdapat enam topik pertanyaan pemandu: informasi yang terkandung dalam jurnal tersebut; makna energy investment, splitting, generation phase; peran laktat dehidrogenase; informasi yang diperoleh pada topik "glycolysis and shuttle pathway"; hubungan antara glikolisis dan kanker; dan aktivator dan inhibitor yang terlibat dalam proses glikolisis.

Pengerjaan artikel ini dilakukan dengan menggunakan dua proses pembelajaran yang mengacu kepada pembelajaran aktif, yaitu mahasiswa belajar secara terarah dan dilakukan secara mandiri (Direct Study/ $D S)$, kemudian secara kelompok untuk mendiskusikan hasil pekerjaan mandiri (Discussion Group/DG). Kegiatan DS dilakukan di luar waktu perkuliahan tatap muka, sedangkan kegiatan DG dilakukan pada saat perkuliahan tatap muka. Pada DS, mahasiswa menjawab pertanyaan pemandu seperti disebutkan sebelumnya. Selanjutnya pada tahap DG, mahasiswa mendiskusikan hasil jawaban mereka secara berkelompok dan membandingkan serta saling memberikan komentar atas jawaban yang telah dikerjakan.

Data yang diperoleh dalam penelitian adalah hasil belajar mahasiswa berupa 
pretest dan posttest. Data lainnya diperoleh dari lembar kuisioner tentang persepsi dan komitmen mahasiswa terhadap pembelajaran dengan menggunakan artikel ilmiah. Kuisioner persepsi dan komitmen mahasiswa telah dikembangkan oleh Cicuto et al. (2019) dan memiliki nilai konsistensi internal (realibilitas) rata-rata sebesar 0,81 (ideal). Konsistensi internal kuisioner ditentukan dengan menggunakan Cronbach's alpha. Validitas kuisioner persepsi dan komitmen mahasiswa telah dinyatakan valid oleh tiga orang validator.

Instrumen tes yang digunakan untuk mengetahui hasil belajar mahasiswa berbentuk esai dengan jumlah soal sebanyak tujuh soal. Sebelum dilakukan penelitian, dilakukan pengembangan terhadap instrumen tes yang digunakan berupa uji tingkat validitas oleh tim dosen yang tergabung dalam KBK Biokimia di PS Pendidikan Kimia FKIP ULM. Berdasarkan hasil uji validitas instrumen dinyatakan bahwa instrumen valid untuk digunakan.

Hasil belajar mahasiswa diperoleh dari nilai pretest dan posttest yang dianalisis dengan menggunakan panduan evaluasi hasil belajar mahasiswa yang berlaku di Universitas Lambung Mangkurat. Nilai pretest dan posttest dilakukan uji beda dengan menggunakan uji peringkat bertanda Wilcoxon untuk menentukan terjadi perbedaan yang signifikan antara hasil pretest dan posttest atau tidak. Tingkat signifikasi dilihat berdasarkan nilai $p$ yang diperoleh.
Hasil belajar mahasiswa juga dilihat berdasarkan nilai indeks gain yang diperoleh dari pretest dan posttest. Indeks gain merupakan besaran yang dapat menggambarkan seberapa besar peningkatan yang diperoleh oleh subjek penelitian akibat perlakukan yang telah diberikan. Interpretasi dari hasil indeks gain dapat dilihat pada Tabel 1. Indeks gain dapat dihitung dengan menggunakan persamaan (1).

$N$-gain $=\frac{\text { skor post test-skor pretest }}{\text { skor maksimum-skor pretest }}$

Hasil persepsi mahasiswa terhadap strategi pembelajaran yang dilakukan dan komitmen mahasiswa terhadap strategi tersebut dianalisis dengan menggunakan skala Likert. Pada lembar kuisioner terdapat komponen yang dapat dilihat seperti pada Tabel 2. Perhitungan kuisioner mahasiswa untuk setiap kategori dihitung dengan menggunakan persamaan (2).

$$
\text { Nilai rata-rata }=\frac{\text { Jumlah } \text { skor }}{\text { Jumlah } \text { item }}
$$

Penilaian persepsi dan komitmen mahasiswa mengacu pada acuan penilaian perepsi dan komitmen mahasiswa pada Tabel 3.

\section{HASIL PENELITIAN DAN PEMBAHASAN}

Hasil belajar mahasiswa dengan menggunakan artikel ilmiah sebagai sumber

Tabel 1

Kategori N-gain Hasil Pretest dan Posttest

\begin{tabular}{cc}
\hline Indeks Gain & Kategori \\
\hline$g \geq 0,70$ & Tinggi \\
$0,30<g<0,70$ & Sedang \\
$g<0,30$ & Rendah \\
\hline
\end{tabular}

Sumber: Hake, 1999 
Tabel 2

Kategori dalam Kuesioner Persepsi dan Komitmen Mahasiswa

\begin{tabular}{llcc}
\hline \multicolumn{1}{c}{ Kuesioner } & \multicolumn{1}{c}{ Kategori } & $\begin{array}{c}\text { Jumlah } \\
\text { Pernyataan }\end{array}$ & $\begin{array}{c}\text { Nomor } \\
\text { Pernyataan }\end{array}$ \\
\hline $\begin{array}{l}\text { Persepsi mahasiswa } \\
\text { terhadap strategi } \\
\text { pembelajaran }\end{array}$ & $\begin{array}{l}\text { Kegiatan pembelajaran yang telah } \\
\text { digunakan }\end{array}$ & 11 & $1-11$ \\
& $\begin{array}{l}\text { Artikel ilmiah sebagai sumber belajar } \\
\text { Pengembangan keterampilan }\end{array}$ & 7 & $12-18$ \\
& Pemahaman konsep ilmiah & 7 & $19-25$ \\
& Evaluasi proses pembelajaran & 7 & $26-32$ \\
$\begin{array}{l}\text { Komitmen mahasiswa } \\
\text { terhadap kegiatan }\end{array}$ & Pembelajaran terarah & 7 & $33-39$ \\
pembelajaran & Kelompok diskusi & 7 & $1-7$ \\
\hline
\end{tabular}

Tabel 3

Acuan Penilaian Persepsi dan Komitmen

\begin{tabular}{cc}
\hline Indeks Gain & Kategori \\
\hline$\geq 4$ & Tinggi \\
$>2-<4$ & Sedang \\
$\leq 2$ & Rendah \\
\hline
\end{tabular}

belajar biokimia menunjukkan peningkatan. Uji peringkat bertanda Wilcoxon terhadap peningkatan hasil belajar menunjukkan bahwa nilai probabilitas dari pretest dan posttest sebesar 0,001 . Nilai probabilitas ini di bawah nilai signifikansi; $p<0,01$. Nilai ini menunjukkan bahwa $\mathrm{H}_{0}$ ditolak dan penggunaan artikel ilmiah sebagai sumber belajar memberikan pengaruh yang sangat nyata dan signifikan terhadap peningkatan hasil belajar mahasiswa pada konsep metabolisme energi.

Hasil uji $N$-gain terhadap hasil belajar mahasiswa menunjukkan rata-rata skor sebesar 0,35 dan berada pada kategori "sedang". Skor $N$-gain tertinggi sebesar 1,00 dengan frekuensi 2 orang mahasiswa dan terendah sebesar - 0,25 dengan frekuensi yang sama, yaitu 2 orang mahasiswa. $\mathrm{N}$-gain negatif diperoleh sebanyak 3 orang mahasiswa, yaitu - 0,25 sebanyak 2 orang dan $-0,10$ sebanyak 1 orang. Hasil ini menunjukkan bahwa terdapat tiga orang mahasiswa yang mengalami penurunan hasil belajar.

Persepsi dan komitmen mahasiswa terhadap proses pembelajaran dilihat dengan menggunakan kuisioner yang dikembangkan oleh Cicuto et al. (2019). Kuisioner berisi 39 item tentang persepsi mahasiswa terhadap strategi pembelajaran yang dilakukan dan 13 item tentang komitmen mahasiswa untuk melaksanakan kegiatan pembelajaran. Strategi pembelajaran ini menggunakan kombinasi antara pem-belajaran terarah $(D S)$ dan diskusi kelompok $(D G)$. Tabel 4 menunjukkan data persepsi dan komitmen mahasiswa.

Tabel 4 menunjukkan bahwa secara klasikal, persepsi mahasiswa terhadap pembelajaran dengan menggunakan artikel ilmiah sebagai sumber belajar, berada pada kategori "sedang" dengan nilai rata-rata sebesar 3,83 dan standar deviasi 
Tabel 4

Persepsi dan Komitmen Mahasiswa terhadap Proses Pembelajaran

\begin{tabular}{lll}
\hline \multicolumn{1}{c}{ Kuisioner } & \multicolumn{1}{c}{ Komponen } & \multicolumn{1}{c}{$\begin{array}{c}\text { Rata-rata } \\
(n=22)\end{array}$} \\
\hline $\begin{array}{l}\text { Persepsi mahasiswa terhadap } \\
\text { strategi pembelajaran }\end{array}$ & Kegiatan pembelajaran yang telah digunakan & $3,69 \pm 0,16$ \\
& Artikel ilmiah sebagai sumber belajar & $3,68 \pm 0,11$ \\
& Pengembangan keterampilan & $4,09 \pm 0,26$ \\
& Pemahaman konsep ilmiah & $4,00 \pm 0,18$ \\
& Evaluasi proses pembelajaran & $3,69 \pm 0,42$ \\
Komitmen mahasiswa & Rata-rata & $3,83 \pm 0,20$ \\
terhadap kegiatan & Pembelajaran terarah & $3,39 \pm 0,58$ \\
pembelajaran & Kelompok diskusi & $3,96 \pm 0,72$ \\
& Rata-rata & $3,68 \pm 0,40$ \\
\hline
\end{tabular}

sebesar 0,20. Komponen pengembangan keterampilan dan pemahaman konsep ilmiah berada pada kategori "tinggi" yaitu dengan nilai rata-rata di atas 4,00 . Sedangkan komponen lainnya berada pada kategori "sedang". Komitmen mahasiswa terhadap pembelajaran, baik pembelajaran terarah maupun kelompok, berada pada kategori "sedang" dengan nilai rata-rata 3,68 dan standar deviasi 0,40.

Berdasarkan pertanyaan terbuka yang disajikan pada kuisioner, mahasiswa memberikan respons positif berkaitan dengan pembelajaran DS \& DG dengan menggunakan artikel ilmiah sebagai sumber pembelajaran. Berdasarkan respons mahasiswa terhadap pembelajaran yang dilakukan, dapat dikelompokkan menjadi beberapa kategori. Berikut adalah contoh dari respons mahasiswa terhadap pembelajaran dengan menggunakan artikel ilmiah.

Pertama, persepsi dalam pemahaman konsep ilmiah.

"Melalui DG, kami dalam satu kelompok dapat saling berkomunikasi dan bertukar pendapat mengenai persoalan yang dibahas".

"Pada DS, saya dapat lebih mandiri dalam memahami artikel konsep metabolisme serta lebih fokus daripada belajar menggunakan buku”.

"Saya dapat membangun hubungan antara konsep metabolisme yang dibahas dalam pembelajaran ini dengan apa yang sudah saya pelajari sebelumnya".

Salah seorang mahasiswa memberikan pendapat yang lebih lengkap berkaitan dengan cara pembelajaran yang digunakan.

"Menurut saya pada saat DS, pemahaman saya meningkat tentang metabolisme tetapi hanya saja jika sendiri, masih ada beberapa istilah ilmiah yang masih kurang paham. Dan terus, masih bingung dengan kegunaan beberapa senyawa di dalam metabolisme, tetapi secara keseluruhan sudah bisa memahami",

Kedua, persepsi dalam hal pengembangan keterampilan.

"Berdasarkan hal tersebut, keterampilan yang dapat berkembang adalah kemampuan dalam berkomunikasi saat diskusi, penerjemahan bahasa ilmiah". "Keterampilan yang saya dapat yaitu keterampilan berpikir kritis, 
yaitu menghubungkan materi yang satu ke yang lain sangat sulit karena rata-rata materi pada Biokimia ini berhubungan. Jika tidak paham materi sebelumnya maka akan sulit untuk memahami materi berikutnya".

Ketiga, persepsi mahasiswa terhadap artikel ilmiah sebagai sumber belajar.

"Cukup baik, agar lebih memahami konsep yang diajarkan, kita perlu artikel yang bersangkutan dengan kehidupan sehari-hari (fenomena yang terjadi) sehingga lebih meningkatkan pemahaman tentang konsep metabolisme".

"Merupakan suatu ide yang bagus, sebab akan mendapatkan informasi baru dari sebuah artikel ilmiah".

"Membuat mahasiswa lebih memahami konsep materi tersebut dalam pengaplikasiannya. Namun saya dapat memahami suatu artikel dengan waktu yang lama dan dengan cara berdiskusi”.

Keempat, saran mahasiswa terhadap pembelajaran yang dilakukan dengan menggunakan artikel ilmiah sebagai sumber pembelajaran.

"Untuk meningkatkan pemahaman melalui startegi pembelajaran sebaiknya lebih mengoptimalkan penjelasan tentang konsep metabolisme dan lebih sering melakukan diskusi".

"Sebaiknya pembelajaran tersebut ditugaskan secara berkemlompok terlebih dahulu lalu dikerjakan secara individu dengan soal yang berbeda namun level yang sama".

Selain persepsi mahasiswa, pada kuisioner disertakan pertanyaan terbuka berkaitan dengan komitmen mahasiswa dalam penggunaan artikel ilmiah sebagai sumber belajar dan peran mahasiswa pada saat diskusi kelompok. Jawaban mahasiswa terhadap dua pertanyaan tersebut memberikan tanggapan yang positif dan tidak terdapat tanggapan negatif atas pertanyaan yang disajikan pada kuisioner. Secara umum, beberapa jawaban mahasiswa atas pertanyaan yang diberikan adalah sebagai berikut.

Pertama, komitmen mahasiswa untuk menggunakan artikel ilmiah sebagai sumber belajar.

"Saya akan berusaha mempelajari artikel ilmiah itu dan memahaminya, namun untuk memahami artikel tersebut saya memerlukan waktu yang sangat lama”.

"Komitmen saya dalam mempelajari artikel ilmiah adalah masih kurang berkomitmen sehingga saya akan meningkatkan karena masih ada halhal yang saya tidak bisa, seperti memspersiapkan, mencari-cari artikel lain yang relevan dengan materi diskusi”.

Kedua, respons mahasiswa berkaitan dengan keterlibatan dalam kegiatan diskusi kelompok.

"Keterlibatan saya dalam kegiatan diskusi kelompok adalah saya berpartisipasi aktif dalam kegiatan diskusi, jika ada perbedaan pendapat saya akan mencari informasi tersebut diinternet dan akan menyampaikan kepada teman diskusi saya".

"Keterlibatan saya sudah aktif dalam hal untuk mencari solusi dari pertanyaan yang hanya dapat dijawab dari sebuah artikel ilmiah. Selain itu, saya juga melakukan diskusi dengan teman agar mendapatkan informasi penting dari artikel ilmiah tersebut".

Respons mahasiswa tersebut berkaitan dengan persepsi dan komitmen mahasiswa 
dalam pembelajaran dengan menggunakan artikel ilmiah, dapat menjadi sumber informasi kualitatif untuk menggali metode pembelajaran yang sesuai. Metode pembelajaran tersebut adalah metode yang dapat digunakan untuk mahasiswa di perguruan tinggi dan artikel ilmiah sebagai sumber belajarnya.

Hasil penelitian menunjukkan bahwa terjadi peningkatan yang signifikan pada pembelajaran metabolisme energi dengan menggunakan artikel ilmiah sebagai sumber pembelajaran. Pemanfaatan artikel ilmiah sebagai sumber pembelajaran, secara statistika memiliki pengaruh yang nyata terhadap peningkatan hasil belajar mahasiswa. Hasil belajar mahasiswa meningkat seiring dengan kemampuan mahasiswa dalam memahami konsep metabolisme karbohidrat dengan menggunakan artikel ilmiah.

Proses peningkatan pemahaman konsep mahasiswa dalam mempelajari metabolisme energi dengan artikel ilmiah terlihat dari respons mahasiswa dalam pembelajaran. Mahasiswa pada pembelajaran terarah mengalami kesulitan. Kesulitan disebabkan mahasiswa mendapatkan istilah-istilah baru dalam metabolisme, sehingga untuk mengatasi kesulitan tersebut, mahasiswa menggali informasi secara mendalam dengan berbagai media yang tersedia. Kesulitan yang dialami oleh mahasiswa menunjukkan bahwa mahasiswa berpikir dan berupaya untuk mengatasi atau menjawab soal-soal yang disajikan. Kesulitan tersebut kemudian dapat teratasi dengan baik dan terkonfirmasi saat dilakukan diskusi kelompok.

Hasil uji statistik deskriptif dengan menggunakan gain yang ternormalisasi menunjukkan bahwa peningkatan hasil belajar mahasiswa berada pada kategori sedang, yaitu sebesar 0,35. Peningkatan ini menujukkan bahwa artikel ilmiah sebagai sumber pembelajaran dapat membantu mahasiswa dalam meningkatkan hasil belajar. Sementara itu, pemahaman konsep mahasiswa berdasarkan kuisioner persepsi dan komitmen mahasiswa menunjukkan bahwa artikel ilmiah membantu mahasiswa dalam memahami konsep metabolisme. Persepsi ini berada pada kategori tinggi, yaitu sebesar 4,00. Biokimia sebagai ilmu interdisipliner memerlukan suatu pembelajaran yang interdisipliner pula dan bersifat nyata, sehingga dengan artikel ilmiah, sifat Biokimia yang interdisipliner dapat terwujud dengan baik (Espadiola et al., 2010). Selain itu, biokimia yang terus mengalami perkembangan (Bobich, 2008; Bell, 2001), perlu disampaikan kepada mahasiswa, sehingga konsep-konsep biokimia yang mereka pelajari dapat selaras dengan perkembangan biokimia saat ini dan bersifat kontekstual (Se et al., 2008; Anderson et al., 2008).

Dalam mempelajari metabolisme dengan artikel ilmiah adalah mahasiswa mendapatkan beberapa keterampilan yang menunjang mereka dalam aspek ilmiah, selain peningkatan hasil belajar. Setelah belajar metabolisme energi dengan menggunakan artikel ilmiah, mahasiswa mendapatkan keterampilan berpikir kreatif, kolaborasi dengan teman sebaya, analisis dan menyimpulkan materi, Keterampilan berdiskusi dan penambahan wawasan terhadap istilah ilmiah, merupakan hal lain yang diperoleh mahasiswa.

Keterampilan berkomunikasi yang terjadi merupakan keterampilan yang tidak hanya kemampuan untuk menyampaikan pendapat, tetapi juga kemampuan untuk komunikasi disertai dengan istilah-istilah ilmiah baru yang diperoleh saat mengikuti pembelajaran dengan menggunakan artikel ilmiah. Mahasiswa juga mengakui bahwa dengan pembelajaran ini mereka memiliki pemahaman terhadap bahasa 
atau istilah baru yang disajikan pada artikel ilmiah yang dikaji. Keterampilan lainnya adalah kemampuan untuk menganalisis dan menyimpulkan isi dari penelitian. Keterampilan analisis dan menyimpulkan ini telah dibuktikan sebelumnya (Gegner et al., 2009; White, 2002). Keterampilan berikutnya merupakan keterampilan yang sejalan dengan keterampilan abad 21 yaitu keterampulan untuk berkolaborasi dan memiliki kemampuan berpikir kreatif.

Keterampilan yang diperoleh mahasiswa setelah pembelajaran dengan menggunakan artikel ilmiah menunjukkan bahwa mahasiswa mempelajari secara serius dan mendalam terhadap artikel ilmiah yang disajikan. Dengan perilaku yang demikian, kemampuan mahasiswa dalam mengatasi permasalahan mengalami peningkatan. Hal ini dikarenakan, segala keterampilan yang tersaji di atas merupakan keterampilan yang termasuk di dalam keterampilan mengatasi permasalahan (problem-solving skills) (Espadiola et al., 2010). Penggunaan artikel ilmiah dalam pembelajaran telah membantu mahasiswa untuk meningkatkan kemampuan dan keterampilan ilmiah mereka untuk memahami konsep metabolisme dalam biokimia. Hasil penelitian dalam bidang biokimia menunjukkan bahwa artikel ilmiah membantu mahasiswa untuk menguasai konsep dasar, menghubungkan antar konsep dan menerapkan konsepkonsep tersebut (White, 2002).

Pembelajaran dengan buku teks, menyajikan informasi dasar tentang metabolisme. Buku teks menyajikan proses glikolisis, dekarboksilasi oksidatif, siklus Krebs hingga transfer elektron. Akan tetapi, aplikasi dari konsep tersebut pada sebuah kasus, belum dapat dijelaskan pada buku teks. Artikel ilmiah selain membelajarkan konsep metabolisme, juga menyajikan permasalahan yang dapat dijawab dengan konsep metabolisme. Artikel ilmiah dalam pembelajaran metabolisme dapat menjadikan mahasiswa lebih fokus dalam mempejari konsep metabolisme. Hal ini dikarenakan mahasiswa disajikan dengan hal yang terarah pada kasus tertentu.

Persepsi mahasiswa terhadap artikel ilmiah sebagai sumber pembelajaran berada pada kategori sedang dengan skor 3,68. Meskipun hanya berada pada kategori sedang, mahasiswa berpendapat bahwa artikel ilmiah membuat mahasiswa dapat berkolaborasi dengan teman sebaya. Permasalahan berupa membelajarkan metabolisme dengan artikel ilmiah, menuntut mahasiswa untuk saling berdiskusi satu dengan lainnya, baik dalam kondisi diskusi kelompok di dalam kelas, maupun di luar kelas. Diskusi terjadi karena mahasiswa memerlukan rekan sebaya untuk dapat membenarkan dan mengatasi tugas yang diberikan. Dapat dikatakan bahwa artikel yang disajikan untuk dipelajari merupakan permasalahan yang harus dihadapi oleh mahasiswa. Artikel ilmiah merupakan permasalahan yang komplek dan bersifat riil, sehingga mahasiswa belajar secara mandiri untuk dapat memahami artikel ilmiah tersebut. Permasalahan yang kompleks dan riil dapat memacu dan memotivasi mahasiswa untuk dapat mengatasi permasalahan tersebut (Duch, 2001; Duch et al., 2001).

Artikel ilmiah sebagai sumber belajar tidak akan memberikan kesan yang berarti dalam pembelajaran jika hanya ditugaskan untuk dikaji atau dipelajari saja. Artikel ilmiah yang ditugaskan harus disertakan dengan soal pemandu yang dapat memandu mahasiswa untuk mempelajari artikel ilmiah dan tidak lepas dari konteks pembelajaran metabolisme. Proses menjawab soal tersebut, mahasiswa memerlukan teman sebaya untuk dapat saling berbagi informasi dan saling koreksi atas jawaban yang mereka coba untuk tuliskan. Diskusi antar 
sesama mahasiswa didorong oleh rasa ketidakyakinan atas jawaban yang diperoleh untuk menjawab pertayaan pemandu. Diskusi berjalan dan menghasilkan penguatan antarteman sebaya sehingga kemudian mahasiswa dapat menuliskan jawaban mereka pada lembar jawaban. Pada pembelajaran aktif, berbagi informasi dan interaksi sesama mahasiswa merupakan faktor utama dalam pembelajaran yang berbasis pada konstruktivis. Pembelajaran konstruktivis menekankan adanya interaksi dan komunikasi sesama pebelajar sehingga terjadi diskusi (Savin-Baden \& Major, 2004).

Strategi pembelajaran yang digunakan dalam penelitian ini adalah dengan pendekatan pembelajaran aktif serta menggunakan metode pembelajaran terarah dan diskusi kelompok. Kedua metode pembelajaran tersebut merupakan satu kesatuan kegiatan yang diadaptasi dari Cicuto et al. (2019). Pada awalnya mahasiswa disajikan mengenai topik yang dikaji dalam perkuliahan metabolisme. Mahasiswa ditugaskan untuk mengkaji dan melakukan analisis terhadap artikel ilmiah yang telah ditentukan oleh dosen pengajar. Artikel yang dipilih selain merupakan artikel dari junal yang memiliki reputasi, juga konten yang disajikan dapat menjadi landasan mahasiswa dalam mempelajari konsep metabolisme secara keseluruhan. Sebelum mengkaji artikel Mini-review on Glycolysis and Cancer yang ditulis oleh M. Akram, sebelumnya mahasiswa telah diajarkan untuk mengkaji atikel The Intermediate Metabolism of Carbohydrates (Krebs et al., 1973). Artikel pertama ini disajikan sebagai pengenalan awal atau pembiasaan mahasiswa dalam mempelajari artikel ilmiah.

Artikel Mini-review on Glycolysis and Cancer yang ditulis oleh M. Akram disajikan sebagai artikel pembelajaran karena isi artikel menjelaskan secara rinci berkaitan dengan konsep metabolisme dan hubungannya dengan kanker. Artikel yang digunakan sebagai sumber pembelajaran, dianalisis dan dikaji secara individu oleh mahasiswa dengan menggunakan pertanyaan pemandu sebagai acuan dalam mempelajari artikel ilmiah. Pertanyaan pemandu yang disajikan berorientasi pada konstruksi mahasiswa untuk membangun pengetahuannya tentang metabolisme melalui artikel yang disajikan. Gegner et al. (2009) menunjukkan bahwa penekanan suatu hal (melalui pertanyaan pemandu), dapat menarik atensi mahasiswa untuk dapat memahami hal tersebut. Kumpulan pemahaman tersebut, kelak akan terjadi secara komprehensif yang berakhir pada terbangunnya pengetahuan mahasiswa terhadap konsep metabolisme. Kegiatan ini merupakan pembelajaran terarah dan dilakukan di luar jam perkuliahan. Pada bagian ini mahasiswa dituntut untuk belajar mandiri sehingga pengetahuan dapat dibangun secara mandiri oleh mahasiswa.

Pembelajaran berupa diskusi kelompok merupakan bagian berikutnya dalam pembelajaran dengan menggunakan artikel ilmiah. Bagian ini dilaksanakan pada saat tatap muka diperkuliahan. Mahasiswa diminta untuk mediskusikan hasil pekerjaan individu secara berkelompok. Pada bagian ini akan terjadi kegiatan diskusi dan konfirmasi atas jawaban yang telah dikerja-kan oleh mahasiswa secara individu. Kegiat-an ini merupakan kegiatan kolaborasi antar mahasiswa dalam memahami dan mengatasi suatu permasalahan. Diskusi sangat diperlukan untuk mengatasi suatu permasalahan (Savin-Baden \& Major, 2004). Lebih dari itu, diskusi diperlukan untuk membentuk pengetahuan bersama atas permasalahan yang dihadapi (Johnson et al., 1998). Kondisi seperti ini merupakan kondisi 
yang menekankan kepada pembelajaran aktif mahasiswa untuk membentuk pengetahuannya sendiri (Bobich, 2008; Prince, 2004). Dosen berperan sebagai fasiltator dan memberikan penegasan atas hal yang telah dikerjakan oleh mahasiswa (Savin-Baden \& Major, 2004; Uden \& Beaimont, 2006, p. 344).

Proses diskusi memberikan banyak hasil dalam pembelajaran dengan menggunakan artikel ilmiah. Mahasiswa yang sebelumnya tidak mengetahui suatu istilah yang tersaji dalam artikel ilmiah, akan memahaminya setelah diskusi dengan teman sebaya. Selain itu, sharing pengetahuan dalam diskusi dapat menyebabkan sesama mahasiswa memiliki pengetahuan yang setara pada akhirnya setelah diskusi. Memiliki pengetahuan yang setara merupakan tujuan dari adanya diskusi kelompok. Secara rinci, strategi yang dapat digunakan dalam pembalajaran biokimia pada topik metabolisme dengan menggunakan artikel ilmiah sebagai sumber pembelajaran adalah dosen menyajikan gambaran secara umum tentang konsep metabolisme, mahasiswa ditugaskan secara madiri untuk mempelajari dan mengkaji artikel ilmiah yang representatif terhadap konsep metabolisme dengan menggunakan pertanyaan pemandu yang telah dibuat, mahasiswa secara berkelompok melakukan diskusi terhadap jawaban pertanyaan pemandu yang telah dijawab berdasarkan artikel ilmiah yang disajikan, dan hasil diskusi dituliskan di lembar diskusi yang berisi tentang simpulan hasil diskusi untuk setiap pertanyaan pemandu.

Berdasarkan hasil dalam penelitian ini dapat terlihat bahwa pembelajaran dengan menggunakan artikel ilmiah sebagai sumber pembelajaran dan menggunakan metode pembelajaran DS \& DG dapat meningkatkan hasil belajar mahasiswa pada konsep metabolisme.

\section{SIMPULAN}

Berdasarkan hasil penelitian di atas dapat disimpulkan bahwa terjadi peningkatan hasil belajar antara pretest dan posttest pada konsep metabolisme energi. Persepsi dan komitmen mahasiswa terhadap pembelajaran dengan menggunakan artikel ilmiah sebagai sumber belajar berada pada kategori sedang. Peningkatan yang signifikan terjadi antara pretest dan posttest setelah diberikan perlakukan berupa pembelajaran dengan menggunakan artikel ilmiah sebagai sumber pembelajaran biokimia. Selain perbedaan, peningkatan pretest dan posttest menghasilkan nilai $n$-gain yang berada pada kategori sedang. Persepsi mahasiswa terhadap kegiatan pembelajaran yang telah dilakukan, berada pada kategori sedang, persepsi mahasiswa terhadap pemanfaatan artikel ilmiah sebagai sumber belajar, berada pada kategori sedang, persepsi mahasiswa terhadap keterampilan yang dimiliki sebagai hasil pembelajaran, berada pada kategori tinggi, persepsi mahasiswa terhadap pembelajaran dan dampaknya dalam pemahaman konsepkonsep ilmiah, berada pada kategori tinggi, penilaian mahasiswa terhadap stratgei pembelajaran yang telah dilakukan, berada pada kategori sedang. Upaya yang dilakukan mahasiswa untuk menggunakan artikel ilmiah sebagai sumber belajar, terlihat dari komitmen mahasiswa dalam menggunakan artikel ilmiah sebagai sumber belajar. Komitmen mahasiswa berdasarkan penelitian yang dilakukan, berada pada kategori sedang.

\section{DAFTAR PUSTAKA}

Akram, M. (2013). Mini-review on glycolysis and cancer. Journal of Cancer Education, 1(1), 1-4. doi: 10.1007/s13187-013-0486-9.

Anderson, W. L., Mitchell, S. M., \& Osgood, M. P. (2008). Gauging the gaps in 
the students problem-solving skills: Assessment of individual and group use of problem-solving strategies using online discussions. Life Sciences Education, 7, 254-262.

Avikasari, Rukayah, \& Indriayu, M. (2018). Keefektifan penggunaan bahan ajar science literacy terhadap peningkatan prestasi belajar. Jurnal Kependidikan, 2(2), 221-234. doi: $10.21831 / \mathrm{jk} . \mathrm{v} 2 \mathrm{i} 2.19167$.

Bell, E. (2001). The future of education in the molecular life sciences. Nature Reviews Molecular Cell Biology, 16, 221-225. https://doi.org/10.1038/35056610.

Bobich, J. A. (2008). Active learning of biochemistry made easy (for the teacher). Journal of Chemical Education, 85, 234-236.

Cicuto, C., Pazinato, M., \& Torres, B. (2019). Teaching metabolism with scientific articles: A new approach. Biochemistry and Molecuar Biology, 47(1), 85-92. doi:10.1002/bmb.21187.

Cornely, K. (1999). Journal articles as case studies: the new England journal of medicine on lactose intolerance. Journal of College Science Teaching, 29(2), 114-119.

Drake, B. D., Acosta, G. M., \& Smith, R. L. (1997). An effective technique for reading reearch articles-The Japanese KENSHU method. Journal of Chemical Education, 74(2), 186188. doi:10.1021/ed074p186.

Duch, B. J. (2001). Writing problems for deeper understanding. Dalam B. J. Duch, S. E. Groh, \& D. E. Allen, The power of problem-based learning (pp. 47-53). Stylus.

Duch, B. J., Groh, S. E., \& Allen, D. E. (2001). Why problem-based learning? A case study of institutional change in undergraduate education. Dalam B. J. Duch, S. E. Groh, \& D. E. Allen, The power of problem-based learning (pp. 3-11). Stylus.

Duncan, A. P., \& Johnson, R. S. (2007). A "classic papers" approach to teaching undergraduate organometallic chemistry. Journal of Chemical Education, 84(3), 443-446.

Espadiola, M. B., El-Bacha, T., Giannella, T. R., Struchiner, M., da Silva, W. S., \& da Poian, A. T. (2010). Teaching energy metabolisme using scientific articles. Biochemistry and Molecular Biology Education, 38(2), 97-103. doi:10.1002/bmb.20386.

Fortner, R. W. (1999). Using cooperative learning to introduce undergraduates to professional literature. Journal of College Science Teaching, 28(4), 261-265.

Gegner, J. A., Mackay, D. H., \& Mayer, R. E. (2009). Computer-suported aids to maing sense of scientific articles: Cagnitive, motivational, and attitudinal effects. Educational Technology Research and Development, 57, 79-97.

Glazer, F. S. (2000). Journal clubs-a successful vehicle to science literacy: reversing roles in the classroom with student-led discussions of primary literature. Journal of College Science Teaching, 29(5), 320-324.

Hake, R. R. (1999). Analyzing change/gain scores. American Educational Research Association's Division D, Measurement and Research Methodology.

Hartman, A. K., Borchardt, J. N., \& Bozer, A. L. (2017). Making primary literature come alive in the classroom. The Journal of Undergraduate Neuroscience Education, 15(2), R24-R28.

Houde, A. (2000). Student symposia on primary research articles: A window into the world of scientific. Journal of College Science Teaching, 30(3), 184-187. 
Johnson, D. W., Johnson, R. T., \& Smith, K. A. (1998). Cooperative learning returns to college: What evidence is there that it works? Change: The Magazine of Higher Learning, 30(4), 26-35. doi:10.1080/00091389809602629.

Kozeracki, C. A., Carey, M. F., Colicelli, J., \& Levis-Fitzgerald, M. (2006). An intensive primary-literaturebased teaching program directly benefits undergraduate science majors and facilitates their transition to doctoral programs. CBE Life Sciences Education, 5(4), 340-347. doi:10.1187/ cbe.06-02-0144.

Krebs, H. A., Camb., M. A., \& Hamburg, M. D. (1937). The intermediate metabolism of carbohydrate. The Lacet, 736-738.

Levine, E. (2001). Reading your way to scientific literacy: Interpreting scientific articles through smallgroup discussions. Journal of College Science Teaching, 31(2), 122-125.

Mulnix, A. B. (2003). Investigations of protein structure and function using the scientific literature: An assignment for an undergraduate cell physiology course. Cell Biology Education, 2(4), 248-255.doi:10.1187/cbe.03-06-0025.

Prince, M. (2004). Does active learning work? A review of the research. Journal of Engineering Education, 93(3), 223-231.

Rahayu, R., \& Laksono, E. W. (2015). Pengembangan perangkat pembelajaran IPA berbasis problem-based learning di SMP. Jurnal Kependidikan, 45(1), 29-43. doi: 10.21831/jk.v45i1.7184.

Roberts, J. (2009). An undergraduate journal club experience: A lesson in critical thinking. Journal of College Science Teaching, 38(3), 28-31.

Roecker, L. (2007). Introducing students to the scientific literature. Journal of Chemical Education, 84(8), 13801384. doi:10.1021/ed084p1380.

Savin-Baden, M., \& Major, C. H. (2004). Foundation of problem-based learning. Open University Press.

Se, A. B., Passos, R. M., Ono, H. A., \& Hermes-Lima, M. (2008). The use of multiples tools for teaching medical biochemistry. Advances in Physiology Education, 32, 188-192.

Uden, L., \& Beaimont, C. (2006). Technology ang problem-based learning. Information Science Publishing.

Ullrich, L. E., Krafnick, A. J., Dumanis, S. B., \& Forcelli, P. A. (2012). Drugs, the brain, and behavior: A graduate student-run comprehensive course in neuroscience. The Journal of Undergraduate Neuroscience Education, 10(2), A105-A112.

Walczak, M. M., \& Jackson, P. T. (2007). Incorporating information literacy skills into analytical chemistry: an evolutionary step. Journal of Chemical Education, 84(8), 13851390. doi:10.1021/ed084p1385.

White, H. B. (2002). Why does my cruorine change color? Journal of College Science Teaching, 31, 106-111.

Willard, A. M., \& Brasier, D. J. (2014). Controversies in neuroscience: a literature-based course for first year undergraduates that improves scientific confidence while teaching concepts. The Journal of Undergraduate Neuroscience Education, 12(2), A159-A166. 